\title{
Induction of steroidogenesis in immature rat Leydig cells by interleukin-1 $\alpha$ is dependent on extracellular signal-regulated kinases
}

\author{
N Renlund, Y Jo', I Svechnikova, M Holst, D M Stocco'1, O Söder and K Svechnikov \\ Department of Woman and Child Health, Pediatric Endocrinology Unit Q2:08, Karolinska Institute \& University Hospital, Astrid Lindgren Children's Hospital, \\ SE-17176 Stockholm, Sweden \\ ${ }^{1}$ Department of Cell Biology and Biochemistry, Texas Tech University Health Sciences Center, Lubbock, TX 79430, USA
}

(Requests for offprints should be addressed to K Svechnikov; Email: konstantin.svechnikov@kbh.ki.se)

\begin{abstract}
Interleukin-1 $\alpha(\mathrm{IL}-1 \alpha)$ plays an important role in the regulation of immune responses as well as in non-inflammatory events in different types of cells. Here we have investigated the involvement of the extracellular signal-regulated kinase (ERK) cascade in IL-1 $\alpha$-induced steroidogenesis by primary cultures of immature rat Leydig cells. Our findings indicate that protein kinase $\mathrm{C}$ functions as an upstream component of signal transduction from the IL-1 receptor type I (IL-1RI) to the ERK cascade. It was observed that IL-1 $\alpha$ upregulated both steroidogenic acute regulatory (StAR) protein expression and its phosphorylation when compared with controls. Selective inhibition of these mitogen-activated protein kinases (MAPKs) by U0126 enhanced both the expression and phosphorylation of the StAR protein, but suppressed androgen production by the immature Leydig cells as well as dissipating the mitochondrial electrochemical potential $\left(\Psi_{\mathrm{m}}\right)$ in these cells. The evidence that water-soluble cholesterol but not 22R-hydroxycholesterol-stimulated steroidogenesis was inhibited by U0126 suggested that an intact $\Psi_{m}$ across the inner mitochondrial membrane is required for cholesterol translocation and is positively regulated by the ERK cascade. We propose that activation of ERKs by IL- $1 \alpha$ plays a dual role in the regulation of steroidogenesis in immature Leydig cells: these MAPKs downregulate StAR expression and phosphorylation, while at the same time they support an intact $\Psi_{\mathrm{m}}$ across the inner mitochondrial membrane, thereby promoting translocation of cholesterol into the mitochondria of the Leydig cell.
\end{abstract}

Journal of Molecular Endocrinology (2006) 36, 327-336

\section{Introduction}

The multifunctional cytokine interleukin- $1 \alpha$ (IL- $1 \alpha)$ plays an important role in the regulation of immune and inflammatory responses (Dinarello 1989), and furthermore is expressed under normal physiological conditions in tissues that do not belong to the immune system (Tovey et al. 1988), including the Sertoli cells of the testis (Jonsson et al. 1999, Sultana et al. 2000). Two receptors for IL-1, designated, IL-1RI and IL-1 RII, have been identified, with IL-1RI being responsible for signal transduction (Dinarello et al. 1989). Both of these receptors are expressed by the Leydig cells, Sertoli cells and macrophages in the testis (Petersen et al. 2002, Svechnikov et al. 2003).

Recently, we have found that IL- $1 \alpha$ stimulates androgen production by immature, but not adult, Leydig cells (Svechnikov et al. 2001). Subsequent investigations in our laboratory revealed that IL- $1 \alpha$ is a potent inducer of the steroidogenic acute regulatory (StAR) protein in immature but not adult Leydig cells (Svechnikov et al. 2003). This upregulation involves activation of p38 mitogen-activated protein kinase
(MAPK) by IL-1 $\alpha$, indicating that this kinase is an important component of the IL- $1 \alpha$ signaling pathway(s) and, moreover, may be involved in the regulation of steroidogenesis by immature Leydig cells. In addition, our most recent findings that growth hormone- and insulin-like growth factor-I (IGF-I)-stimulated steroidogenesis in immature Leydig cells is dramatically potentiated by IL-1 $\alpha$ (Colon et al. 2005) suggests that this IL may play a key role in the postnatal maturation and development of steroidogenesis in Leydig cells.

The extracellular signal-regulated kinases $1 / 2$ (ERK1/2) belong to the family of MAPKs known to be involved in the regulation of a number of important biological functions, including cell proliferation, differentiation and apoptosis, as well as in carcinogenesis (Lewis et al. 1998). Although several studies have indicated that the ERK cascade participates in the regulation of steroidogenesis in steroid-producing cells (Cameron et al. 1996, Gyles et al. 2001, Seger et al. 2001), the conclusions drawn appear to be contradictory; i.e. both stimulatory (Cameron et al. 1996, Das et al. 1996, Gyles et al. 2001) and inhibitory (Seger et al. 2001, Tajima et al. 2003) effects have been reported. Recently, we have 
demonstrated that ERKs upregulate de novo biosynthesis of StAR along with steroidogenesis in immature rat Leydig cells activated by human chorionic gonadotropin (hCG) (Martinelle et al. 2004). In light of previous indications that IL- $1 \alpha$ promotes the growth and differentiation of testicular cells, our present hypothesis was that the ERK cascade is involved in the induction of steroidogenesis in immature rat Leydig cells in response to IL- $1 \alpha$.

\section{Materials and methods}

\section{Materials}

Dulbecco's modified Eagle's medium (DMEM)/Ham's nutrient mixture F-12, modified Eagle's medium (MEM), Hank's balanced salts solution without $\mathrm{Ca}^{2+}$ and $\mathrm{Mg}^{2+}$, BSA and antibiotics were obtained from Gibco/BRL (Life Technologies, Paisley, Scotland, UK). Trilostane, an inhibitor of $3 \beta$-hydroxysteroid dehydrogenase, was provided by Stegram Pharmaceuticals (Billinghurst, Sussex, UK). Percoll, HEPES, collagenase type I, water-soluble cholesterol and 22Rhydroxycholesterol (22R-OHC) were from Sigma Chemical Co. (St Louis, MO, USA), rat recombinant IL- $1 \alpha$ was from RD Systems (Oxon, Oxfordshire, UK), UO126, Calphostin C and H-89 hydrochloride were from Calbiochem (La Jolla, CA, USA), and antibodies directed specifically against the phosphorylated form of p44/42 MAPK (mouse monoclonal antibody IgG, affinity-purified) or total p44/42 MAPK (rabbit polyclonal IgG, affinity-purified) were from Cell Signaling Technology (Beverly, MA, USA).

\section{Animals}

Testes from 40-day old Sprague-Dawley rats (B\&K Laboratories, Sollentuna, Sweden) were used for the preparation of immature Leydig cells. These animals had access to a standard laboratory pellet diet and water ad libitum. These experiments were approved by the Northern Stockholm Animal Ethics Committee (registration no. N161/04).

\section{Isolation and primary culture of Leydig cells}

Leydig cells were prepared from the testes of immature rats as described previously (Svechnikov et al. 2001). Briefly, following decapsulation, testes were disrupted by collagenase treatment and the seminiferous tubules were separated mechanically. In order to obtain purified Leydig cells, this crude suspension was loaded on the top of a discontinuous gradient consisting of layers of 20, 40, 60 and 90\% Percoll dissolved in Hank's balanced salts solution and subsequently centrifuged at $800 \boldsymbol{g}$ for $20 \mathrm{~min}$. The fractions enriched in Leydig cells thus obtained were then centrifuged in a continuous, self-generating density gradient starting with $60 \%$ Percoll at $20000 \boldsymbol{g}$ for $30 \mathrm{~min}$ at $4{ }^{\circ} \mathrm{C}$.

The purity of these Leydig cell preparations was shown to be $90 \%$, as determined by histochemical staining for $3 \beta$-hydroxysteroid dehydrogenase (Payne et al. 1980). The cell viability, as assessed by Trypan Blue exclusion, was greater than $90 \%$. These purified Leydig cells were resuspended in DMEM/F12 supplemented with $15 \mathrm{mM}$ HEPES (pH 7•4), $1 \mathrm{mg} / \mathrm{ml} \mathrm{BSA}, 365 \mathrm{mg} / \mathrm{l}$ glutamine, $100 \mathrm{IU} / \mathrm{ml}$ penicillin and $100 \mu \mathrm{g} / \mathrm{ml}$ streptomycin.

For culturing, $100 \mu \mathrm{l}$ of a suspension containing $1.5 \times 10^{5}$ cells $/ \mathrm{ml}$ was plated into each well of a 96-well Falcon plate (Falcon, Franklin Lakes, NJ, USA) and incubated for $24 \mathrm{~h}$ at $34{ }^{\circ} \mathrm{C}$ in $5 \% \mathrm{CO}_{2}$. At this time point, fresh culture medium was added and the cells pre-incubated for $30 \mathrm{~min}$ with the selective ERK inhibitor, UO126 $(0 \cdot 1-10 \mu \mathrm{M})$, prior to incubation with IL- $1 \alpha(1 \mathrm{ng} / \mathrm{ml})$, and/or 22R-OHC $(10 \mu \mathrm{M})$, and/or water-soluble cholesterol $(100 \mu \mathrm{M})$ for $24 \mathrm{~h}$. This range of concentrations of UO126 has been earlier demonstrated to inhibit ERK activities without affecting a number of other protein kinases (Davies et al. 2000).

In other experiments, $0.5 \times 10^{6}$ Leydig cells in a total volume of $2 \mathrm{ml}$ were plated into culture dishes $(35 \times 10 \mathrm{~mm}$; Falcon) and then incubated for $24 \mathrm{~h}$ at $34{ }^{\circ} \mathrm{C}$. Thereafter, fresh medium was added and the cells pre-treated with a combination of UO126 $(10 \mu \mathrm{M}), \mathrm{H}-89$ $(10 \mu \mathrm{M})$ and Calphostin $\mathrm{C}(1 \mu \mathrm{M})$, which are selective inhibitors of ERKs, protein kinase $\mathrm{A}$ (PKA) and protein kinase C (PKC) activities, respectively (Davies et al. 2000, Jarvis et al. 1994), followed by incubation with IL-1 $\alpha$ $(1 \mathrm{ng} / \mathrm{ml})$ for $15 \mathrm{~min}$. This treatment was terminated by aspirating the culture medium and rinsing the cells twice with PBS. All compounds except for watersoluble cholesterol were dissolved in DMSO. The final concentration of DMSO in media did not exceed $0 \cdot 1 \%$.

\section{Steroid assays}

Culture medium samples were stored at $-20{ }^{\circ} \mathrm{C}$ prior to analysis of testosterone, dehydroepiandrosterone (DHEA), pregnenolone and $5 \alpha$-androstane- $3 \alpha, 17 \beta$-diol. The sum of testosterone and $5 \alpha$-androstane- $3 \alpha, 17 \beta$-diol, which are the predominant steroids synthesized at this developmental age, was used as an indicator of the total capacity of Leydig cells to produce androgens in culture. Testosterone and DHEA were quantified employing the Coat-a-Count RIA kit (Diagnostic Products Corp., Los Angeles, CA, USA), according to the manufacturer's instructions, while the concentrations of $5 \alpha$-androstane$3 \alpha, 17 \beta$-diol and pregnenolone were determined by RIA using specific antisera (Cosmo Bio Co., Tokyo, Japan 
and Fitzgerald Industries, Concord, MA, USA, respectively). $5 \alpha-\left[9,11-{ }^{3} \mathrm{H}(\mathrm{N})\right]$ Androstane-3 $\alpha, 17 \beta$-diol (specific activity, $40 \mathrm{Ci} / \mathrm{mmol})$ and $\left[{ }^{-3} \mathrm{H}(\mathrm{N})\right]$ pregnenolone (specific activity, $14 \mathrm{Ci} / \mathrm{mmol}$ ) were obtained from NEN Life Science Products (Boston, MA, USA).

\section{Western blot analysis}

The influence of IL- $1 \alpha$ on the degree of phosphorylation of ERK and StAR expression was analyzed by PAGE/ western blotting. For this purpose, the cells were washed twice with PBS and then lysed and sonicated in a buffer containing $62.5 \mathrm{mM}$ Tris/HCl (pH 6.8), 2\% SDS, $50 \mathrm{mM}$ dithiothreitol and $10 \%$ glycerol. Subsequently, the solubilized fraction was collected by centrifugation at $10000 \boldsymbol{g}$ for $6 \mathrm{~min}$. The Leydig cell solubilized proteins (40 $\mu \mathrm{g}$ from each sample) were resolved by electrophoresis on 10\% SDS/polyacrylamide gels and transferred electrophoretically to Hybond-P polyvinylidene difluoride (PVDF) membranes (Amersham Pharmacia Biotech, Little Chalfont, Bucks, UK), using $25 \mathrm{mM}$ Tris/ $\mathrm{HCl}$ and $185 \mathrm{mM}$ glycine, pH 8·3, containing 20\% methanol.

Following this transfer, the membrane was incubated in a blocking buffer (Tris-buffered saline (TBS)/0.1\% Tween (TBST) containing 5\% non-fat dry milk) for $1 \mathrm{~h}$, followed by washing with TBST $(3 \times 10 \mathrm{~min})$. Subsequently, these membranes were incubated with antibodies directed towards phosphorylated or total ERK1/2, according to the manufacturer's specifications (Cell Signaling Tech., Beverly, MA, USA) and, after washing, with donkey anti-rabbit or sheep anti-mouse secondary IgG antibodies.

To assay StAR expression and phosphorylation, membranes were probed with specific antibodies recognizing either total StAR (Bose et al. 1999) or phospho-StAR (generated against a peptide conjugated to keyhole limpet hemocyanin corresponding to amino acid residues 190-199 of mouse StAR, with serine 194 phosphorylated, which was a kind gift from Dr Steven King, Baylor College of Medicine, Houston, TX, USA). Following incubation with the secondary antibody (anti-rabbit, conjugated with horseradish peroxidase), antibody binding was determined using enhanced chemiluminescence (EGL; PerkinElmer Life Sciences, Boston, MA, USA) and detected by exposure to X-ray film (Marsh Bio Products, Rochester, NY, USA). The ECL Hyperfilms were scanned using an HP ScanJet 5100G and HP PrecisionScan software (HewlettPackard Sverige AB, Kista, Sweden) and the extent of antibody binding subsequently quantified utilizing NIH Image 1.57 software.

\section{Measurement of cytochrome P450 scc activity}

In these experiments, intact Leydig cells $\left(2 \times 10^{5}\right.$ cells $/ \mathrm{ml}$ ) were plated into each well of a 96-well Falcon plate (Falcon) and cultured for $24 \mathrm{~h}$ at $34^{\circ} \mathrm{C}$. At this time point, fresh culture medium was added and the cells were pre-incubated for $30 \mathrm{~min}$ with trilostane $(5 \mu \mathrm{M})$, an inhibitor of $3 \beta$-hydroxysteroid dehydrogenase (Potts et al. 1978), and UO126 $(10 \mu \mathrm{M})$ prior to incubation with or without water-soluble cholesterol and IL- $1 \alpha(1 \mathrm{ng} / \mathrm{ml})$ for another $3 \mathrm{~h}$. Since pregnenolone could be converted to DHEA by cytochrome P450c17 via the $\Delta^{5}$ pathway, formation of DHEA was also measured and the sum of the above steroids was considered as an index of $\mathrm{P} 450$ scc activity.

To measure $\mathrm{P} 450 \mathrm{scc}$ activity in homogenates of Leydig cells, the cells $\left(5 \times 10^{5}\right.$ cells $)$ were plated into $35 \mathrm{~mm}$ culture dishes (Falcon) and cultured for $24 \mathrm{~h}$ at $34^{\circ} \mathrm{C}$. Then cells were pre-incubated for $30 \mathrm{~min}$ with UO126 $(10 \mu \mathrm{M})$ prior to incubation with or without IL-1 $\alpha(1 \mathrm{ng} / \mathrm{ml})$ for $2 \mathrm{~h}$. The cells were then washed twice with ice-cold PBS, scraped and sonicated $(2 \times 5 \mathrm{~s})$ in a buffer containing $0.25 \mathrm{M}$ sucrose, $10 \mathrm{mM}$ Tris/HCl (pH 7·4), 1 mM EGTA and a protease-inhibitor cocktail (Roche). Debris was removed from the homogenates by centrifugation at $600 \boldsymbol{g}$ for $10 \mathrm{~min}$ at $4{ }^{\circ} \mathrm{C}$, followed by transfer of the supernatant to a new tube. Protein concentration was determined by the Bradford method (Bradford 1976).

To assay P450 scc enzyme activity, homogenates from all treated groups were incubated in the presence of NADPH $(0.5 \mathrm{mM})$, trilostane $(5 \mu \mathrm{M})$ and water-soluble cholesterol $(50 \mu \mathrm{M})$ in a final volume of $100 \mu \mathrm{l}$. After 1-h incubation at $37^{\circ} \mathrm{C}$, the reaction was stopped by centrifugation at $14000 \mathrm{~g}$ for $10 \mathrm{~min}$ at $4{ }^{\circ} \mathrm{C}$ and pregnenolone and DHEA were measured by RIA.

\section{Assay of mitochondrial membrane potential}

Mitochondrial membrane potential $\left(\Psi_{\mathrm{m}}\right)$ was measured with JC-1 (Molecular Probes, Eugene, OR, USA), a fluorescent dye which detects the mitochondrial membrane potential in cells. Cells were pre-treated for 30 min with UO126 $(10 \mu \mathrm{M})$ prior to incubation for another $30 \mathrm{~min}$ with or without IL- $1 \alpha(1 \mathrm{ng} / \mathrm{ml})$. Then cells were incubated with JC-1 $(10 \mu \mathrm{g} / \mathrm{ml})$ for $15 \mathrm{~min}$ at $34^{\circ} \mathrm{C}$ and carefully washed with medium to remove unincorporated dye and then fresh media was added back to the cells. Fluorescence was determined using $550 \mathrm{~nm}$ excitation and $600 \mathrm{~nm}$ emission filters for red J-aggregate fluorescence $\left(\Psi_{\mathrm{m}}\right.$-sensitive $)$ and $485 \mathrm{~nm}$ excitation and $535 \mathrm{~nm}$ emission filters for green fluorescence $\left(\Psi_{\mathrm{m}}\right.$-insensitive) using a Wallac1420 microplate spectrofluorometer (Perkin Elmer). When the electrochemical potential is intact, the negative charge established by the intact mitochondrial membrane potential allows the dye to enter the mitochondrial matrix where it accumulates forming J-aggregates which become fluorescent red. If the electrochemical potential is lost, JC-1 exists in the monomeric form and stains the 
cytosol green. The mitochondrial membrane potential $\Psi_{\mathrm{m}}$ was estimated as the ratio of red to green JC-1 fluorescence.

\section{Microscopy}

Cells were cultured for $24 \mathrm{~h}$ on cover glasses placed in 12 -well plates. Then cells were pre-treated for $30 \mathrm{~min}$ with UO126 $(10 \mu \mathrm{M})$ prior to incubation with or without IL- $1 \alpha(1 \mathrm{ng} / \mathrm{ml})$ for $24 \mathrm{~h}$ and fixed with $4 \%$ paraformaldehyde at room temperature for $20 \mathrm{~min}$, and permeabilized with $0 \cdot 3 \%$ Triton X-100 for 5 min. After washing, they were incubated in blocking buffer $(0 \cdot 2 \%$ BSA in TBS) for $20 \mathrm{~min}$ at room temperature followed by incubation with primary rabbit anti-StAR polyclonal antibody at 1:100 dilution and then with secondary Gy3-conjugated donkey anti-rabbit antibodies (Jackson ImmunoResearch Labs). The cells were viewed with a Nikon fluorescence microscope (Nikon, Bergstrom Inst., Solna, Sweden).

\section{Statistical analysis}

The differences between various values were analysed for statistical significance by one-way analysis of variance (ANOVA) followed by the Student-Newman-Keul test, using the SigmaStat (version 3.00) package (SPSS, Chicago, IL, USA). $P<0 \cdot 05$ was considered to be statistically significant.

\section{Results}

\section{IL-1 $\alpha$ stimulates phosphorylation of ERK1/2 in a time-dependent manner}

Following the overnight culturing of immature Leydig cells, activation of their ERK1/2 by IL- $1 \alpha$ was assessed after exposing the cells to this cytokine for different periods of time. Elevation in phosphorylation of ERK1/2 was detectable within 5 min of exposure to IL- $1 \alpha$, attained a maximum level after $15 \mathrm{~min}$ and returned to control levels within $1 \mathrm{~h}$ of initiation of treatment (Fig. 1).

\section{PKC, but not PKA, is involved in the phosphorylation of ERK1/2 caused by IL-1 $\alpha$}

In order to identify the upstream kinases involved in the IL- $1 \alpha$-stimulated activation of ERK1/2, the cells were exposed to H-89 or Calphostin G. Under conditions where treatment of the immature Leydig cells with IL- $1 \alpha$ alone resulted in a 7 -fold increase in the level of phosphorylated ERK1/2, Calphostin C inhibited this activation by approximately $50 \%$ whereas $\mathrm{H}-89$ was without any significant effect (Fig. 2). These observations

\section{Time (min) of treatment with IL-1 $\alpha$}

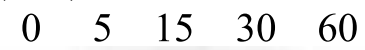

$44 \mathrm{kDa}$

$42 \mathrm{kDa}$

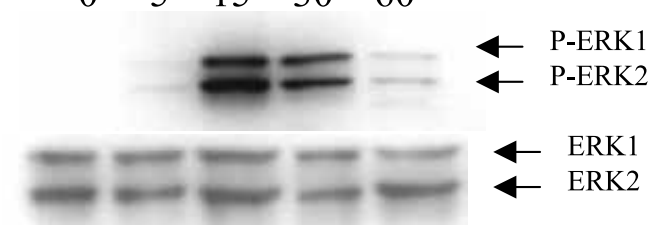

Figure 1 Time-course of activation of ERK1/2 in immature Leydig cells by IL- $1 \alpha$. After incubation with IL- $1 \alpha(1 \mathrm{ng} / \mathrm{ml})$ for different periods of time, the cultured cells were lysed and $40 \mu \mathrm{g}$ total protein were used to analyze phosphorylated (P-ERK1/2; upper panel) and total (lower panel) ERK1/2 protein levels by Western blotting. Similar results were obtained in two other experiments.

indicate the upstream involvement of PKC but not PKA in the pathway that transduces signals from IL-1 receptors to ERK1/2. As expected, the enhanced phosphorylation of these MAPKs induced by IL- $1 \alpha$ was completely abolished by UO126, a selective inhibitor of the ERK cascade (Fig. 3).

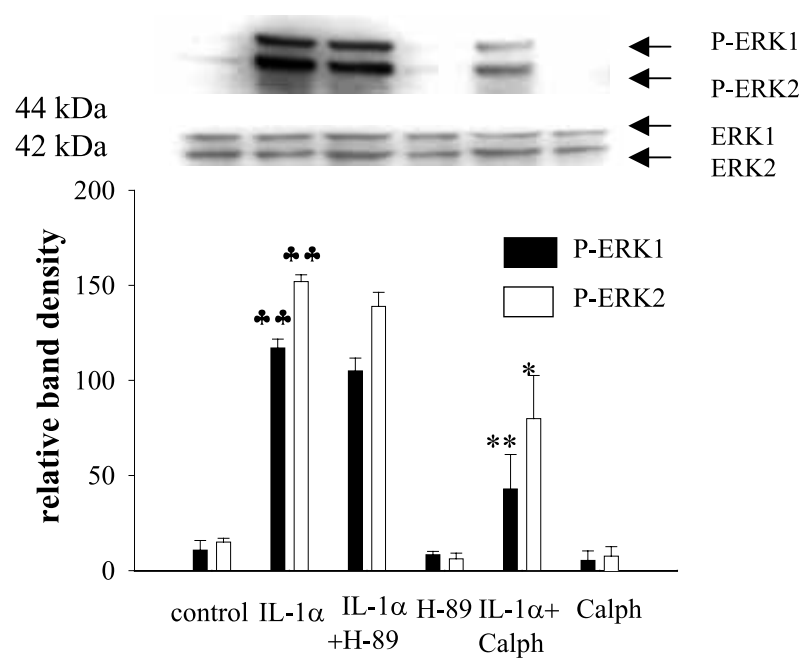

Figure $2 \mathrm{PKC}$ is an upstream component of the pathway resulting in activation of MAPKs in Leydig cells in response to IL-1 $\alpha$. Cells were pretreated with $10 \mu \mathrm{M} \mathrm{H}-89$ or $1 \mu \mathrm{M}$ Calphostin C (Calph), selective inhibitors of PKA and PKC respectively, or standard medium alone for $30 \mathrm{~min}$ and then stimulated with IL-1 $\alpha(1 \mathrm{ng} / \mathrm{ml})$ for an additional $15 \mathrm{~min}$. Whole cell lysates (40 $\mu \mathrm{g}$ protein) were analyzed for phosphorylated and total ERK1/2 protein by western blotting (upper panel). Each band containing phosphorylated ERK1/2 (P-ERK1/2) was quantified by densitometric scanning using NIH Image software and expressed in relative densitometric units (lower panel). The means \pm S.E.M. for three independent Leydig cell preparations are presented. $P<0.01$ compared with untreated cells; ${ }^{*} P<0.05$ and ${ }^{* *} P<0.01$ compared with cells treated with IL-1 $\alpha$ alone. 


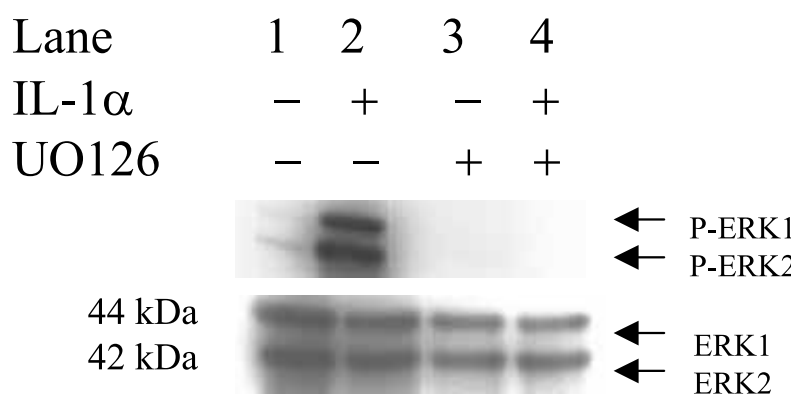

Figure 3 UO126 inhibits the increase in phosphorylation of ERK $1 / 2$ in immature Leydig cells exposed to IL-1 $\alpha$. Cultured cells were pretreated with $10 \mu \mathrm{M}$ UO126 or standard medium alone for $30 \mathrm{~min}$ and then stimulated with IL-1 $\alpha(1 \mathrm{ng} / \mathrm{ml})$ for $15 \mathrm{~min}$. The cells were subsequently lysed and $40 \mu \mathrm{g}$ total lysate protein used to analyze phosphorylated and total ERK1/2 protein by western blotting. Similar results were obtained in two other experiments.

\section{Inhibition of the activation of ERK1/2 in immature Leydig cells exposed to IL-1 $\alpha$ suppresses steroid production}

The role of ERK1/2 in IL- $1 \alpha$-induced steroidogenesis by immature Leydig cells was examined using UO126, a selective inhibitor for MAPK/ERK kinase (MEK), the upstream kinase for ERK1/2. Following UO126 treatment the production of both testosterone and its $5 \alpha$-reduced form, $5 \alpha$-androstane- $3 \alpha, 17 \beta$-diol, were inhibited in a dose-dependent fashion (Fig. 4).

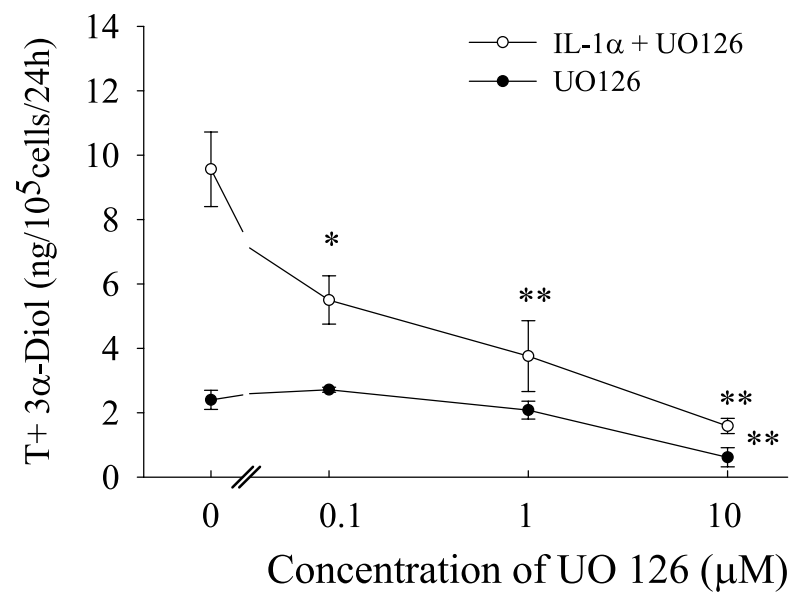

Figure 4 U0126 inhibits the IL- $1 \alpha$ activation of steroidogenesis in immature Leydig cells. Cultured Leydig cells were pretreated with different concentrations of U0126 for 30 min and then incubated with IL-1 $\alpha(1 \mathrm{ng} / \mathrm{ml})$ or standard medium alone for an additional $24 \mathrm{~h}$. Testosterone (T) and $5 \alpha$-androstane- $3 \alpha, 17 \beta$-diol ( $3 \alpha$-Diol) in the culture medium were then measured by RIA and the results expressed as ng/105 cells per $24 \mathrm{~h}$. Each experiment was performed four times independently obtaining similar results. ${ }^{*} P<0.05$ and ${ }^{* *} P<0.01$ compared with treatment with IL-1 $\alpha$ and vehicle.
Furthermore, $10 \mu \mathrm{M}$ UO126 also significantly inhibited basal steroidogenesis in these Leydig cells.

\section{The site of action of U0126 on IL-1 $\alpha$-stimulated steroidogenesis in immature Leydig cells}

In an attempt to locate the site of action of UO126, the effect of this inhibitor on the production of steroids by immature Leydig cells from both water-soluble cholesterol and a cell-permeable form of cholesterol, 22R$\mathrm{OHC}$, was investigated. Water-soluble cholesterol was found to significantly stimulate steroidogenesis in immature Leydig cells (a 20-fold increase compared with control). Subsequently, co-treatment of the cells with UO126 and cholesterol or cholesterol and IL- $1 \alpha$ resulted in 4and 3-fold decreases in androgen production, respectively (Fig. 5A). In contrast, UO126 did not inhibit steroidogenesis induced by the membrane-permeable derivative of cholesterol, 22R-OHC, alone or in combination with IL-1 $\alpha$ (Fig. 5B). These findings suggest that the ERK cascade may be involved in the regulation of cholesterol translocation from the outer to the inner mitochondrial membrane and/or the hydroxylation of cholesterol at the $\mathrm{C}_{22}$ position by mitochondrial cytochrome $\mathrm{P} 450 \mathrm{scc}$.

\section{Influence of UO126 on the level of expression and degree of phosphorylation of StAR in IL-1 $\alpha$-stimulated immature rat Leydig cells}

We examined whether the inhibition of the ERK cascade by UO126 affects IL- $1 \alpha$-induced synthesis and phosphorylation of the StAR protein. As expected, IL- $1 \alpha$ alone induced StAR expression significantly (a 25-fold increase compared with unstimulated cells) and detectably enhanced the level of phosphorylated StAR (Fig. 6A). Subsequently, treatment with both IL- $1 \alpha$ and UO126 resulted in a further 2-fold increase in the level of total StAR expression, as well as an 18-fold elevation in the level of its phosphorylated form. UO126 alone also markedly stimulated StAR expression but not StAR phosphorylation.

The increased expression of StAR protein induced in cultured immature Leydig cells by IL- $1 \alpha$ was accompanied by a 5 -fold stimulation of androgen production, an effect that was dramatically attenuated by UO126, despite an even higher level of expression and phosphorylation of StAR (Fig. 6B). Similarly, this inhibitor also suppressed basal steroidogenesis by Leydig cells.

\section{U0126 inhibits the transfer of cholesterol into mitochondria of immature Leydig cells}

To further examine whether the ERK cascade is involved in the regulation of cholesterol transport across mitochondrial membranes or the hydroxylation of 


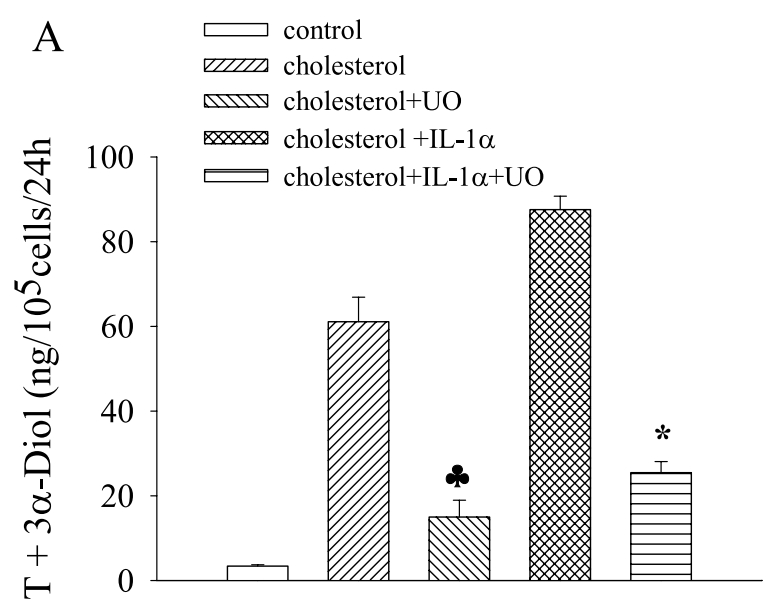

$\mathrm{B}$

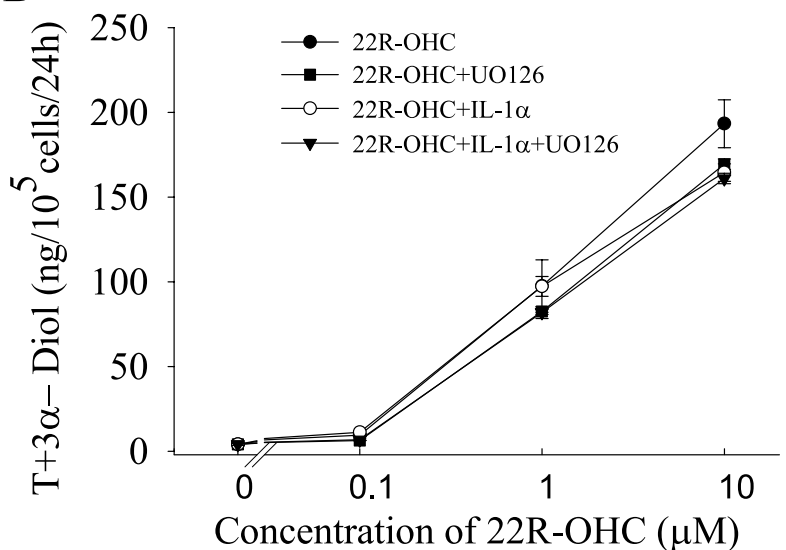

Figure 5 Effect of UO126 on water-soluble cholesterol- and 22R-OHC-stimulated androgen production in cultured immature rat Leydig cells. Leydig cells were pretreated with UO126 (UO; $10 \mu \mathrm{M})$ for $30 \mathrm{~min}$ and thereafter incubated with cholesterol $(100 \mu \mathrm{M})(\mathrm{A})$ or different concentrations of $22 \mathrm{R}-\mathrm{OHC}$

$(0.1-10 \mu \mathrm{M}) ;(B)$ in the presence or absence of IL-1 $\alpha(1 \mathrm{ng} / \mathrm{ml})$ for $24 \mathrm{~h}$. Androgen levels in the medium were then measured by RIA. Each experiment was performed independently three times with similar results. $* 0<05$ compared with treatment with cholesterol; * $P<0.05$ compared with treatment with cholesterol and IL-1 $\alpha$.

cholesterol at the $\mathrm{C}_{22}$ position by mitochondrial cytochrome $\mathrm{P} 450 \mathrm{scc}$, we measured the activity of cytochrome P450 scc directly in whole Leydig cells or in Leydig cell homogenates using water-soluble cholesterol as substrate. Co-treatment of cells with UO126 and cholesterol or cholesterol and IL- $1 \alpha$ resulted in a 5- and 7 -fold decrease in steroid production, respectively (Fig. 7A). In contrast, when the mitochondrial membranes were destroyed and cholesterol had free access to cytochrome $\mathrm{P} 450$ scc in the cell homogenates, UO126 had no significant effect on the activity of this enzyme (Fig. 7B), indicating that ERKs control the
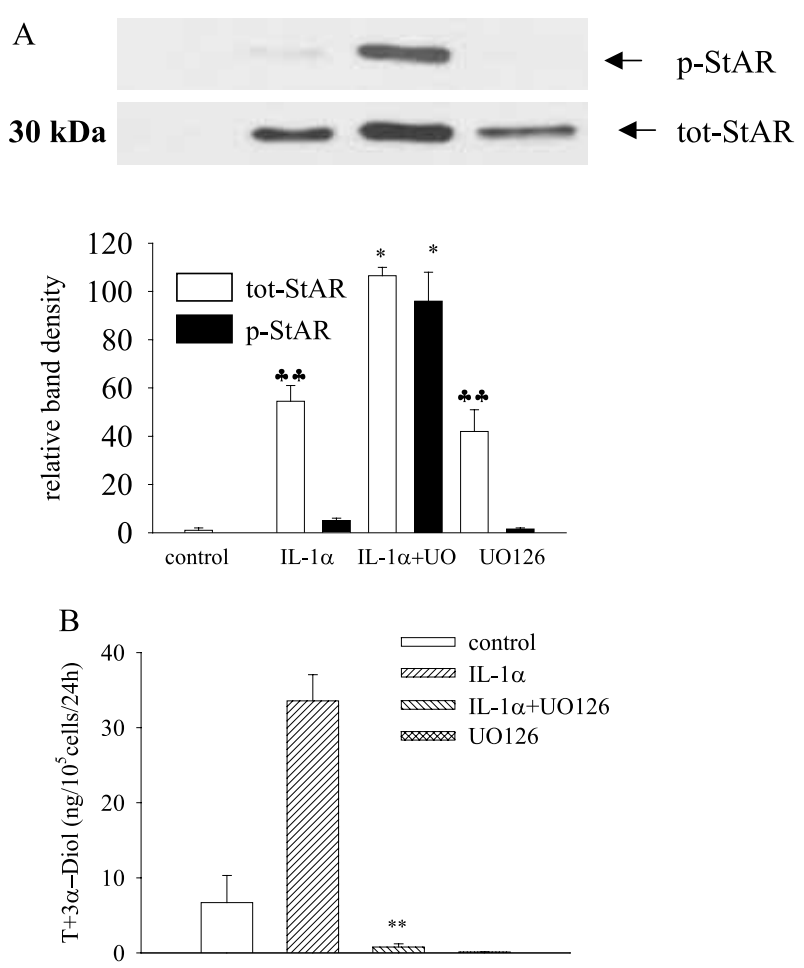

Figure 6 Effects of U0126 on the expression and phosphorylation of StAR and on androgen production by immature Leydig cells stimulated with IL-1 $\alpha$. Cells were pretreated with $10 \mu \mathrm{M}$ UO126 or culture medium alone for $30 \mathrm{~min}$, followed by incubation with IL-1 $\alpha(1 \mathrm{ng} / \mathrm{ml})$ for $24 \mathrm{~h}$. (A) The cells were lysed and whole cell lysates ( $40 \mu \mathrm{g}$ protein) employed to analyze the levels of phosphorylated and total StAR protein by western blotting as described in the Materials and methods section. The data were quantified and expressed as described in the legend to Fig. 2. The positions of total StAR (tot-StAR) and its phosphorylated forms ( $p-S t A R)$ are indicated by arrows. (B) The total level of androgens secreted in the medium was assayed by RIA. In both $A$ and $B$, the means \pm S.E.M. for three independent Leydig cell preparations are presented. $P<0.01$ compared with untreated cells; ${ }^{*} P<0.05$ and ${ }^{* *} P<0.01$ compared with cells treated with IL-1 $\alpha$ alone.

transfer of cholesterol across the mitochondrial membrane without affecting activity of P450 scc.

\section{Inhibition of the ERK1/2 by U0126 decreases the mitochondrial membrane potential in IL-1 $\alpha$-activated immature Leydig cells}

Since StAR-induced steroidogenesis requires maintenance of an electrochemical gradient across the inner mitochondrial membrane (King et al. 1999), we further examined whether UO126 could alter the mitochondrial electrochemical potential in immature Leydig cells. We observed a significant $46 \%$ decline in the red/green ratio of JC-1 fluorescence following treatment with UO126 in both control and IL- $1 \alpha$-treated cells (Fig. 8). 

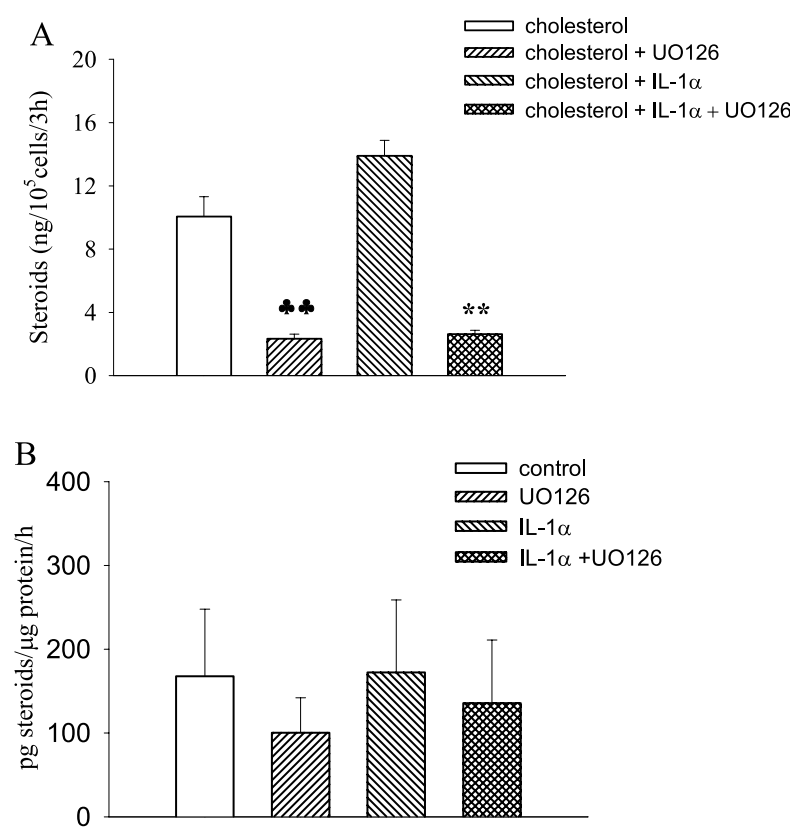

Figure 7 Effect of UO126 on P450 scc activity in whole Leydig cells and their homogenates. (A) Leydig cells were initially incubated with $5 \mu \mathrm{M}$ trilostane and $10 \mu \mathrm{M}$ UO126 for 30 min prior to incubation with or without cholesterol $(100 \mu \mathrm{M})$ and $\mathrm{IL}-1 \alpha(1 \mathrm{ng} / \mathrm{ml})$ for $3 \mathrm{~h}$. (B) Leydig cells were treated as described in the Materials and methods section and their homogenates were incubated with NADPH (0.5 mM), trilostane $(5 \mu \mathrm{M})$ and cholesterol $(50 \mu \mathrm{M})$ for $1 \mathrm{~h}$. Pregnenolone and DHEA levels in the medium and supernatant of homogenates were measured by RIA. Each experiment was performed independently three times with similar results. $P<0.01$ compared with treatment with cholesterol; ${ }^{* *} P<0.01$ compared with treatment with cholesterol and IL- $1 \alpha$.

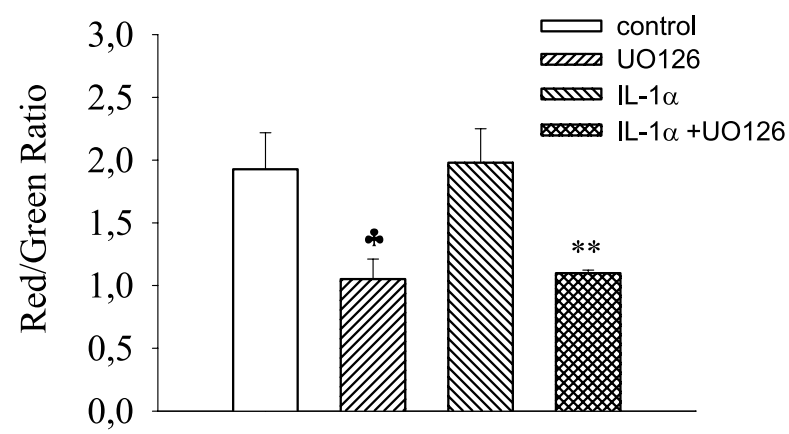

Figure 8 U0126 inhibits mitochondrial membrane potential $\left(\Psi_{m}\right)$ in immature Leydig cells. Leydig cells were pretreated with UO126 $(10 \mu \mathrm{M})$ for $30 \mathrm{~min}$ and thereafter incubated with $\mathrm{IL}-1 \alpha(1 \mathrm{ng} / \mathrm{ml})$ for another $30 \mathrm{~min}$. The measurement of $\Psi_{\mathrm{m}}$ in a 96-well plate was done as described in the Materials and methods section. Each experiment was performed independently three times with similar results. $* P<0.05$ compared with untreated cells; ${ }^{* *} P<0.01$ compared with treatment with IL-1 $\alpha$.
This observation reflects the loss of the mitochondrial electrochemical potential in these cells.

\section{Subcellular localization of StAR in immature Leydig cells treated with IL-1 $\alpha$ and U0126}

To examine whether the UO126- and IL- $1 \alpha$-induced elevation of StAR expression was located in the mitochondria, immature Leydig cells were stained with anti-StAR antibodies after treatment with IL- $1 \alpha$ with or without UO126. Using specific antibodies to StAR, immunocytochemistry revealed that StAR was undetectable in mitochondria in non-stimulated cells (Fig. 9A). In contrast, clear elevation in mitochondrial StAR was evident after $24 \mathrm{~h}$ of treatment with UO126 (Fig. 9B). IL- $1 \alpha$ markedly increased the mitochondrial StAR content (Fig. 9D), and co-treatment with UO126 significantly enhanced IL- $1 \alpha$-stimulated mitochondrial StAR content (Fig. 9C).

\section{Discussion}

The present study demonstrates that the ERK cascade participates in the regulation of steroidogenesis and is a component of the signaling pathways initiated by IL- $1 \alpha$ in the immature Leydig cell. Thus, selective inhibition of the ERKs attenuates IL- $1 \alpha$-induced steroidogenesis in immature rat Leydig cells despite enhanced expression and phosphorylation of the StAR protein. In contrast, steroidogenesis is not affected by UO126 when a membrane-permeable form of cholesterol (22R-OHC) is used as a substrate in these cells in both the absence and presence of IL-1 $\alpha$. Further, we demonstrated that at high concentrations the water-soluble form of cholesterol is transfered across the mitochondrial membrane and can bypass StAR function and stimulate steroidogenesis, a process inhibited by UO126. This form of cholesterol is a complex of cholesterol with methyl- $\beta$-cyclodextrin, which enhance solubility of this steroid in aqueous solution (Irie et al. 1992). Moreover, cholesterol from such a complex was found to easily incorporate into the erythrocyte membrane (Irie et al. 1992), suggesting that the same process may enhance cholesterol level in the mitochondrial membrane of Leydig cells. To exclude the possible effects of UO126 on the hydroxylation of cholesterol at the $\mathrm{C}_{22}$ position by mitochondrial cytochrome $\mathrm{P} 450$ scc, we measured the activity of cytochrome P450 scc both in intact Leydig cells and in homogenates using water-soluble cholesterol as a substrate. Inhibition of ERK activity by UO126 had no effect on the activity of P450 scc in the cell homogenates, a condition in which the integrity of the mitochondrial membranes was in all probability altered, whereas this process was inhibited in whole cells. Together, these 


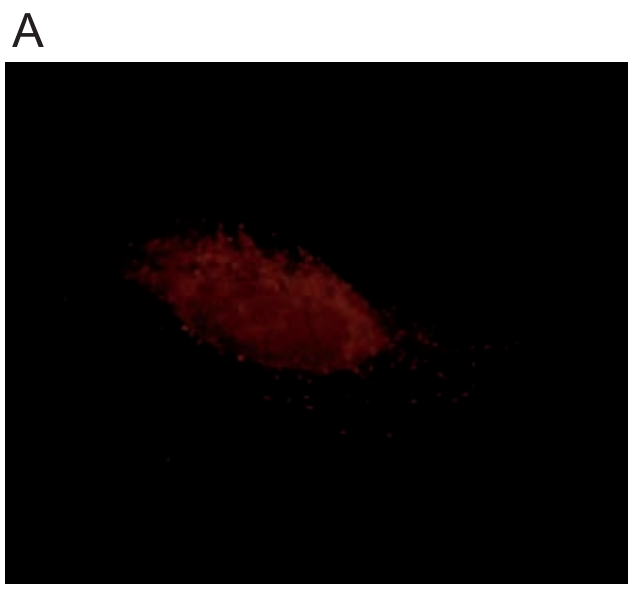

B
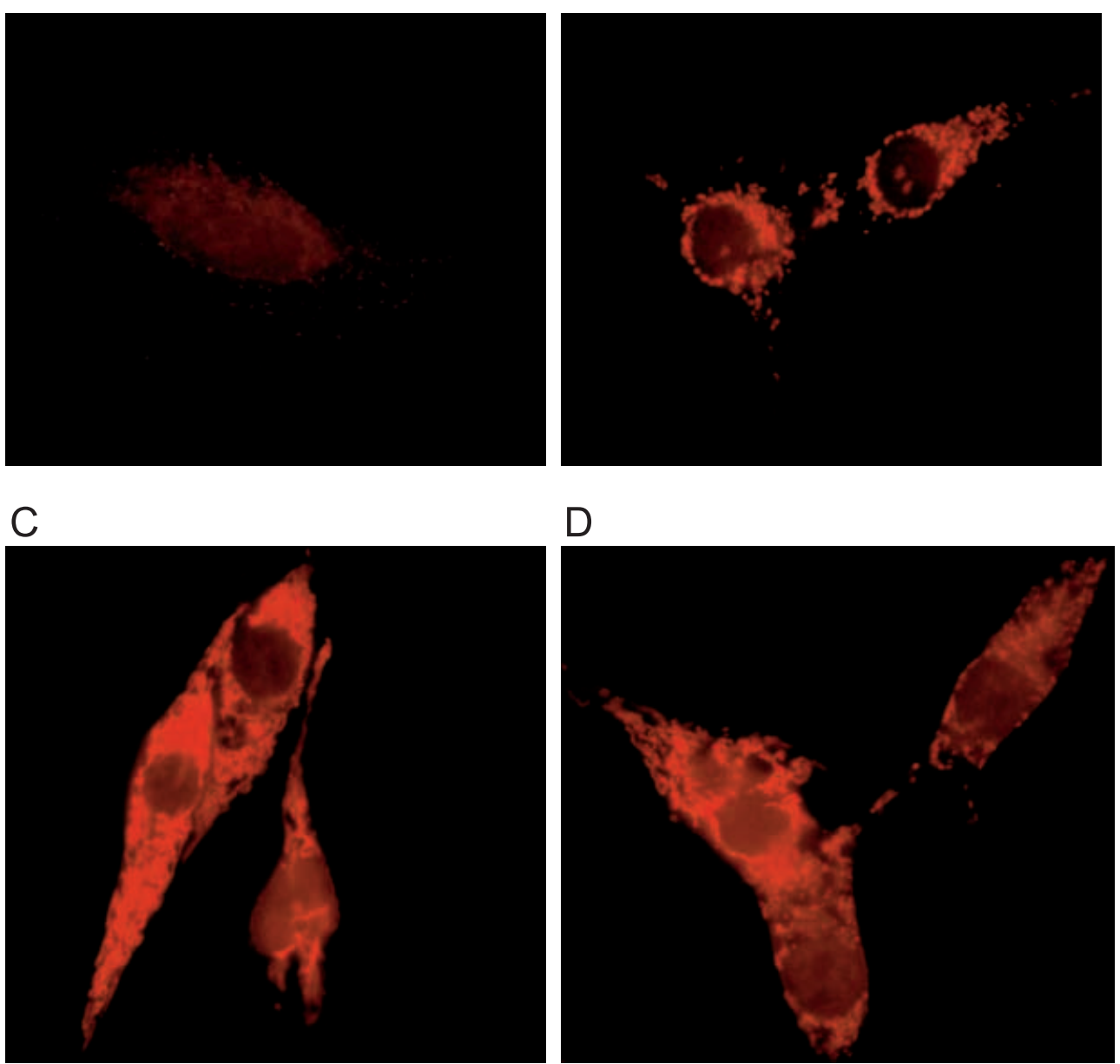

Figure 9 Subcellular localization of StAR on induction with IL-1 $\alpha$ and UO126. Leydig cells were pre-treated with UO126 $(10 \mu \mathrm{M})$ for 30 min prior to incubation with or without IL-1 $\alpha(1 \mathrm{ng} / \mathrm{ml})$ for $24 \mathrm{~h}$. The cells were then subjected to immunofluorescence using anti-StAR antibodies, followed by donkey anti-rabbit IgG conjugated to Cy 3. (A) Untreated control; (B) $24 \mathrm{~h}$ incubation with UO126; (C) $24 \mathrm{~h}$ incubation with IL-1 $\alpha$ and UO126; (D) $24 \mathrm{~h}$ incubation with IL-1 $\alpha$.

findings indicate that the ERKs are involved in the regulation of cholesterol trafficking from the outer mitochondrial membrane to the inner mitochondrial membrane and do not influence the activities of downstream steroidogenic enzymes. In addition, our observation that UO126 dissipates the mitochondrial electrochemical potential in immature Leydig cells (quantified as the ratio of red/green JC-1 fluorescence) suggests that ERKs stimulated by IL- $1 \alpha$ control mitochondrial integrity and function. To the best of our knowledge, this finding provides the first example of modulation of mitochondrial function in steroidogenic cells by the ERK cascade. The observation that cholesterol- but not 22R-OHC-stimulated steroidogenesis was inhibited by UO126 also indicated that an intact $\Psi_{\mathrm{m}}$ across the inner mitochondrial membrane is required for cholesterol translocation into the matrix as well as for StAR function and import (King et al. 1999). Furthermore, our findings demonstrate that PKC functions as an upstream kinase in the transduction of the signal from IL-1RI to the ERK cascade.

We observed that inhibition of ERKs enhanced the expression and phosphorylation of StAR while simultaneously causing a dramatic decrease in androgen production by Leydig cells. In an attempt to explain these contradictory observations, we speculate that after traversing the outer mitochondrial membrane, a step which does not require $\Psi_{\mathrm{m}}$ (Granot et al. 2003), StAR and cholesterol probably remain trapped and accumulate in the intermembrane space of mitochondria without import into the mitochondrial matrix due to dissipation of $\Psi_{\mathrm{m}}$ induced by UO126. This possibility is 
in agreement with the finding that the expression of C-28 StAR, a nonfunctional StAR mutant having uncoupling activity, leads to a loss of $\Psi_{\mathrm{m}}$ and capture of the truncated protein in the intermembrane space without import into the mitochondrial matrix (Granot et al. 2003). In addition, this finding is in line with a recently published report demonstrating that MEK inhibition increases basal and IGF-I-mediated StAR expression, but decreases progesterone synthesis in mouse Leydig tumor cells (Manna et al. 2005).

Taken together, our findings are in agreement with the general notion that StAR protein functions to translocate cholesterol from the outer to the inner mitochondrial membrane (Stocco 2001), and that cholesterol requires an intact $\Psi_{\mathrm{m}}$ for its further transfer to the mitochondrial matrix. In addition, recent studies have shown that StAR acts exclusively on the outer mitochondrial membrane (Arakane et al. 1996, Bose et al. 2002) and, after being imported into the mitochondrion, presumably plays no further role in steroidogenesis (Bose et al. 2002). It has also been reported that accumulation of StAR can potentially damage mitochondria (Granot et al. 2002, 2003) but we found no changes in viability in UO126-treated cells compared with control cells (as assessed using the cell-proliferation reagent WST-1; data not shown).

Reports concerning the potential involvement of ERK1/2 in the regulation of steroidogenesis in different steroid-producing cells appear to be contradictory, some documenting stimulatory effects (Cameron et al. 1996, Das et al. 1996, Gyles et al. 2001, Martinelle et al. 2004) and others inhibitory effects (Seger et al. 2001, Tajima et al. 2003). For example, several investigations have shown that luteinizing hormone and follicle-stimulating hormone activate ERK1/2 and enhance steroid production in ovarian cells (Cameron et al. 1996, Das et al. 1996), whereas stimulation of the ERK cascade by these same gonadotropins in cell lines derived from granulosa cells was observed to suppress steroidogenesis (Seger et al. 2001, Tajima et al. 2003). In the present study, it was demonstrated that inhibition of IL-1 $\alpha$ activated ERKs in immature Leydig cells enhanced the level of StAR expression, but decreased steroidogenesis, an observation in agreement with previous reports (Manna et al. 2005, Martinat et al. 2005).

In a recent study, we have demonstrated that ERKs enhanced the acute stimulatory effects of hCG on de novo synthesis of StAR, which were associated with increased androgen production in Leydig cells (Martinelle et al. 2004). In contrast, these MAPKs are involved in the downregulation of StAR expression and steroidogenesis that is observed after long-term (24-48 h) treatment of granulosa-derived cell lines with such activators (Seger et al. 2001). Thus the mechanisms underlying acute and long-term inhibition of ERK in steroid-producing cells may be different, involving modulation of the expression of various transcription factors and/or of other proteins participating in the regulation of steroidogenesis. In view of the heterogeneity of signaling from hCG/luteinizing hormone and IL-1RI receptors, it is not surprising that the same MAPKs exert variable effects on the regulation of steroidogenesis in Leydig cells. Moreover, differences in the nature of the second messenger systems linked to cell-surface receptors, as well as the variety of overlapping and interacting signal pathways that are functional in various cell lines and tissues, may also help explain these seemingly contradictory findings.

The upstream events that lead to activation of the ERK cascade upon binding of IL- $1 \alpha$ to the IL-1RI have not yet been elucidated. The single relevant report to date demonstrated that tumor necrosis factor $\alpha$ and cAMP can modulate ERK activities in MA-10 mouse Leydig tumor cells (Li et al. 1997). Although we show here that in immature rat Leydig cells PKG is involved in the upstream machinery by which IL-1 $\alpha$ regulates the ERK cascade, inhibition of PKC by Calphostin $\mathrm{C}$ only inhibits ERK phosphorylation by $50 \%$, suggesting that other kinases could be involved in the phosphorylation of ERK1/2 in these cells. On the basis of findings in other cell types, it can be suggested that this signaling includes activation of phospholipase $\mathrm{C}$, which in turn hydrolyzes phospholipids to liberate diacylglycerol (Dinarello 1991). Diacylglycerol might then trigger PKC to phosphorylate Raf and activate the ERK cascade (Cai et al. 1997).

In summary, our present investigation demonstrates that activation of the ERK cascade by IL- $1 \alpha$ plays a dual role in the regulation of steroidogenesis in immature Leydig cells. These MAPKs downregulate the expression and phosphorylation of StAR, while at the same time positively regulating an intact $\Psi_{\mathrm{m}}$ across the inner mitochondrial membrane. As androgens promote the differentiation of Leydig cells (Buzek et al. 1988, Misro et al. 1993), we hypothesize that the ERK activities represent an important feature of the functions of IL- $1 \alpha$ as a growth and differentiation factor for Leydig cells.

\section{Acknowledgements}

This work was supported by grants from the Swedish Research Council (project 8282) the Frimurare Barnhuset Foundation in Stockholm, the Swedish Children's Cancer Fund, the Swedish Environmental Protection Agency, HRH Crown Princess Lovisa's Society for Pediatric Health Care, the Society for Child Care, Wera Ekström Foundation for Pediatric Research and the Karolinska Institute, and with funds from NIH grant HD-17481 and Robert A. Welch Foundation grant B1-0028. The authors declare that there is no conflict of interest that wouldprejudice the impartiality of this scientific work.

Journal of Molecular Endocrinology (2006) 36, 327-336 


\section{References}

Arakane F, Sugawara T, Nishino H, Liu Z, Holt JA, Pain D, Stocco DM, Miller WL \& Strauss JF 3rd 1996 Steroidogenic acute regulatory protein (StAR) retains activity in the absence of its mitochondrial import sequence: implications for the mechanism of StAR action. PNAS 93 13731-13736.

Bose HS, Whittal RM, Baldwin MA \& Miller WL 1999 The active form of the steroidogenic acute regulatory protein, StAR, appears to be a molten globule. PNAS 96 7250-7255.

Bose H, Lingappa VR \& Miller WL 2002 Rapid regulation of steroidogenesis by mitochondrial protein import. Nature 417 87-91.

Bradford MM 1976 A rapid and sensitive method for the quantitation of microgram quantities of protein utilizing the principle of protein-dye binding. Analytical Biochemistry 72 248-254.

Buzek SW \& Sanborn BM 1988 Increase in testicular androgen receptor during sexual maturation in the rat. Biology of Reproduction $3939-49$.

Cai H, Smola U, Wixler V, Eisenmann-Tappe I, Diaz-Meco MT, Moscat J, Rapp U \& Cooper GM 1997 Role of diacylglycerolregulated protein kinase $\mathrm{C}$ isotypes in growth factor activation of the Raf-1 protein kinase. Molecular \& Cellular Biology 17 732-741.

Cameron MR, Foster JS, Bukovsky A \& Wimalasena J 1996 Activation of mitogen-activated protein kinases by gonadotropins and cyclic adenosine $5^{\prime}$-monophosphates in porcine granulosa cells. Biology of Reproduction 55 111-119.

Colon E, Svechnikov KV, Carlsson-Skwirut C, Bang P \& Soder O 2005 Stimulation of steroidogenesis in immature rat Leydig cells evoked by interleukin-1 alpha is potentiated by growth hormone and insulin-like growth factors. Endocrinology 146 221-230.

Das S, Maizels ET, DeManno D, St Clair E, Adam SA \& Hunzicker-Dunn M 1996 A stimulatory role of cyclic adenosine $3^{\prime}, 5^{\prime}$-monophosphate in follicle-stimulating hormone-activated mitogen-activated protein kinase signaling pathway in rat ovarian granulosa cells. Endocrinology 137 967-974.

Davies SP, Reddy H, Caivano M \& Cohen P 2000 Specificity and mechanism of action of some commonly used protein kinase inhibitors. Biochemical fournal 351 95-105.

Dinarello CA 1989 Interleukin-1 and its biologically related cytokines. Advances in Immunology 44 153-205.

Dinarello CA 1991 Interleukin-1 and interleukin-1 antagonism. Blood 77 1627-1652.

Dinarello CA \& Savage N 1989 Interleukin-1 and its receptor. Critical Reviews in Immunology 9 1-20.

Granot Z, Silverman E, Friedlander R, Melamed-Book N, Eimerl S, Timberg R, Hales KH, Hales DB, Stocco DM \& Orly J 2002 The life cycle of the steroidogenic acute regulatory (StAR) protein: from transcription through proteolysis. Endocrine Research $\mathbf{2 8}$ 375-386.

Granot Z, Geiss-Friedlander R, Melamed-Book N, Eimerl S, Timberg R, Weiss AM, Hales KH, Hales DB, Stocco DM \& Orly J 2003 Proteolysis of normal and mutated steroidogenic acute regulatory proteins in the mitochondria: the fate of unwanted proteins. Molecular Endocrinology 17 2461-2476.

Gyles SL, Burns CJ, Whitehouse BJ, Sugden D, Marsh PJ, Persaud SJ \& Jones PM 2001 ERKs regulate cyclic AMP-induced steroid synthesis through transcription of the steroidogenic acute regulatory (StAR) gene. Fournal of Biological Chemistry $\mathbf{2 7 6}$ 34888-34895.

Irie T, Fukunaga K \& Pitha J 1992 Hydroxypropylcyclodextrins in parenteral use. I: Lipid dissolution and effects on lipid transfers in vitro. Fournal of Pharmaceutical Science 81 521-523.

Jarvis WD, Turner AJ, Povirk LF, Traylor RS \& Grant S 1994 Induction of apoptotic DNA fragmentation and cell death in HL-60 human promyelocytic leukemia cells by pharmacological inhibitors of protein kinase C. Cancer Research 54 1707-1714.
Jonsson CK, Zetterström RH, Holst M, Parvinen M \& Söder O 1999 Constitutive expression of interleukin-1 alpha messenger ribonucleic acid in rat Sertoli cells is dependent upon interaction with germ cells. Endocrinology 140 3755-3761.

King SR, Liu Z, Soh J, Eimerl S, Orly J \& Stocco DM 1999 Effects of disruption of the mitochondrial electrochemical gradient on steroidogenesis and the Steroidogenic Acute Regulatory (StAR) protein. Fournal of Steroid Biochemistry and Molecular Biology 69 143-154.

Lewis TS, Shapiro PS \& Ahn NG 1998 Signal transduction through MAP kinase cascades. Advances in Cancer Research 74 49-139.

Li X, Hales KH, Watanabe G, Lee RJ, Pestell RG \& Hales DB 1997 The effect of tumor necrosis factor-alpha and cAMP on induction of AP-1 activity in MA-10 tumor Leydig cells. Endocrine 6 317-324.

Manna PR, Chandrala SP, King SR, Jo Y, Counis R, Huhtaniemi IT \& Stocco DM 2005 Molecular mechanisms of insulin-like growth factor-I mediated regulation of the steroidogenic acute regulatory protein in mouse Leydig cells. Molecular Endocrinology In Press.

Martinat N, Crepieux P, Reiter E \& Guillou F 2005 Extracellular signal-regulated kinases (ERK) 1, 2 are required for luteinizing hormone ( $\mathrm{LH}$-induced steroidogenesis in primary Leydig cells and control steroidogenic acute regulatory (StAR) expression. Reproduction and Nutrition Development 45 101-108.

Martinelle N, Holst M, Soder O \& Svechnikov K 2004 Extracellular signal-regulated kinases are involved in the acute activation of steroidogenesis in immature rat Leydig cells by human chorionic gonadotropin. Endocrinology 145 4629-4634.

Misro MM, Ganguly A \& Das RP 1993 Is testosterone essential for maintenance of normal morphology in immature rat Leydig cells? International Fournal of Andrology 16 221-226.

Payne AH, Downing JR \& Wong KL 1980 Luteinizing hormone receptors and testosterone synthesis in two distinct populations of Leydig cells. Endocrinology 106 1424-1429.

Petersen C, Boitani C, Fröysa B \& Söder O 2002 Interleukin-1 is a potent growth factor for immature rat sertoli cells. Molecualr and Cellular Endocrinology 186 37-47.

Potts GO, Creange JE, Hardomg HR \& Schane HP 1978 Trilostane, an orally active inhibitor of steroid biosynthesis. Steroids 32 257-267.

Seger R, Hanoch T, Rosenberg R, Dantes A, Merz WE, Strauss JF 3rd \& Amsterdam A 2001 The ERK signaling cascade inhibits gonadotropin-stimulated steroidogenesis. Fournal of Biological Chemistry 276 13957-13964.

Stocco DM 2001 StAR protein and the regulation of steroid hormone biosynthesis. Annual Reviewes in Physiology 63 193-213.

Sultana T, Svechnikov K, Weber G \& Söder O 2000 Molecular cloning and expression of a functionally different alternative splice variant of prointerleukin-1 alpha from the rat testis. Endocrinology $1414413-4418$.

Svechnikov KV, Sultana T \& Söder O 2001 Age-dependent stimulation of Leydig cell steroidogenesis by interleukin-1 isoforms. Molecular and Cellular Endocrinology 182 193-201.

Svechnikov K, Stocco DM \& Söder O 2003 Interleukin-1 alpha stimulates steroidogenic acute regulatory protein expression via p38 MAP kinase in immature rat Leydig cells. Fournal of Molecular Endocrinology 30 59-67.

Tajima K, Dantes A, Yao Z, Sorokina K, Kotsuji F, Seger R \& Amsterdam A 2003 Down-regulation of steroidogenic response to gonadotropins in human and rat preovulatory granulosa cells involves mitogen-activated protein kinase activation and modulation of DAX-1 and steroidogenic factor-1. Fournal of Clinical Endocrinology and Metabolism 88 2288-2299.

Tovey MG, Content J, Gresser I, Gugenheim J, Blanchard B, Guymarho J, Poupart P, Gigou M, Shaw A \& Fiers W 1988 Genes for IFN-beta-2 (IL-6), tumor necrosis factor, and IL-1 are expressed at high levels in the organs of normal individuals. Fournal of Immunology 141 3106-3110.

Received 27 November 2005

Accepted 9 December 2005 